is funded by the STA. The Center, the main site of which is due for completion in Yokohama next year, focuses on three areas of research: human and mouse cDNA sequencing and functional genomics for both humans and mice; development of a "gene encyclopedia" of the mouse genome; and the analysis of protein function and structure using nuclear magnetic resonance.

The STA has also been allotted $¥ 9.2$ billion (US\$81 million) for a new project encompassing bioinformatics and investigation of information processing in the brain. The project is part of a new interministerial program bringing together life sciences and information sciences, and is supported by the one-off appropriation as part of its "social infrastructure program.”

The Ministry of International Trade and Industry (MITI; Tokyo) saw an overall decrease of $0.2 \%$ in its biotechnology-related budget due to what is seen as MITI's shift toward application-oriented research. However, there were notable increases in biotechnology-related budgets for programs supporting "commercially applicable" research. The ministry received $¥ 2.7$ billion (US\$24 million) for the infrastructure program and a $56.5 \%$ increase in funding for a program aimed at strengthening Japan's intellectual property protection.

And the Japanese Patent Office (JPO; Tokyo), which comes under the auspices of MITI, is planning to expand its patent database to create an electronic "patent library" for the commercialization of patent information. The move follows the government's initiative to improve commercial exploitation of patents by academic scientists in Japan, who have a poor record in seeking patent protection for their inventions.

Since the passing of a new law to promote university/industry collaboration last May, an increasing number of university researchers have started to take up entrepreneurial activities. Both MITI and the Ministry of Education, Science, Sports and Culture (Monbusho; Tokyo) are actively backing programs to set up technology liaison offices (TLOs), which help draw up contracts for collaboration with industrial laboratories and advise on the commercial application of invention made by university researchers.

Monbusho has also been backing Venture Business Laboratories, a program begun in 1996 to develop closer ties between academic research and the industrial community. Venture Business Laboratories have so far been set up at 24 national universities, providing laboratories for joint research projects and training programs for students and researchers who wish to set up their own small companies to commercialize university research.

Also in the budget, the Ministry of Agriculture, Fisheries and Forestry (MAFF; Tokyo) received $¥ 1.4$ billion for "green frontier research," a new project to promote bioremediation research. And the Ministry of Health and Welfare (MHW; Tokyo), which saw an $8.5 \%$ increase in its biotechnology-related budget, received $¥ 2.6$ billion for gene therapy and human genome research. The continuing growth in support for gene therapy reflects the recent increase in number of institutions in Japan carrying out gene therapy research.

Asako Saegusa

\title{
deCODE looks forward as database law passes
}

The bill that would allow deCODE Genetics (Reykjavik) to establish a centralized database of Iceland's health records was voted into law in the Icelandic Parliament on December 17, 1998. As stipulated in the new law, it will be at least six months before any data can be entered into the database. During that time, the licensee to the database, which is still likely to be deCODE, will have to negotiate with hospitals, research faculties, and individual physicians with regard to data access.

Einar Stefänsson, chairman of the department of ophthalmology at the National University Hospital (Reykjavik), hopes that now that the law has passed, those involved will be able to begin working constructively together. He says that loose phrasing in draft bills caused much of the "angst" that echoes around the medical and research communities. He believes that the detailed regulations under the law and negotiations with potential data providers will "lay to rest some of the worries." Stefänsson, who has been a proponent of the idea of the centralized database for some time, is already working with deCODE on the genetics of diseases of the eye.

A leading opponent of the law, Jon Johanes Jonsson (National University Hospital), believes that one of the law's new provisions may make researchers think twice about collaboration with the licensee. $\mathrm{He}$

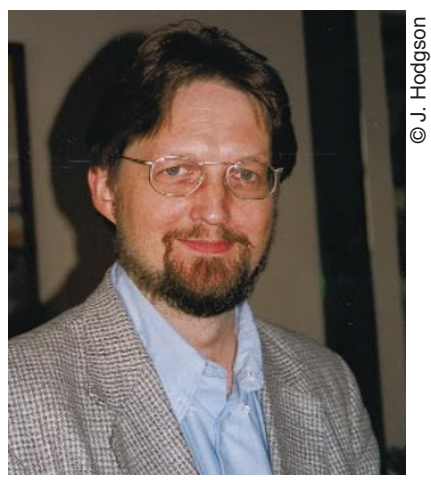

Jonsson: Researchers using the database will forfeit all rights to the exploitation of their research.

says that a researcher contributing data to the database and using the data from it will forfeit all rights to the exploitation of their research. "This is clearly stated," he says. He thinks that the central database will be "biased and patchy" because many researchers will bypass the database and establish their own collaborations with drug companies.

Jonsson does highlight one significant change from earlier drafts that he believes is an improvement. This is a provision that allows a patient to request at any time that any new information on him or her not be entered and that existing information be withdrawn. The same request, unless rescinded, would also apply to information recorded in the future.

The details of implementation of the information withdrawal request will be one of the first tasks for Iceland's new director general of public health (surgeon-general), Sigurdur Gudmundsson. Gudmundsson, a database "enthusiast," has only been at his post since the beginning of December.

deCODE's CEO, Kari Stefänsson, hopes that by the end of 1999, the database will include "a significant amount" of health data from the various medical establishments. To support this, the company will be taking on extra staff in the next few months. Stefansson believes that the negotiations for access to data will be part of a healing process in the Icelandic medical community. "I think people will be reassured. There are already indications that the opposition [to the law] is becoming narrower and narrower." Stefansson says he has been approached by a number of former opponents of the central database who are now seeking to open collaborations.

Stefansson feels that the debate that raged around the issue in 1998 has been a valuable process. "There was lots of participation-as much as we have ever seen over any matter of science-based policy. It was painful, vigorous and sometimes angry.... But now we can go forward."

John Hodgson 